\title{
SAMOARHIVIRANJE ZNANSTVENIH RADOVA NA AKADEMSKIM DRUŠTVENIM MREŽAMA: \\ ANALIZA MOGUĆNOSTI
}

\author{
SELF-ARCHIVING OF SCIENTIFIC PAPERS \\ ON ACADEMIC SOCIAL NETWORKS: AN ANALYSIS \\ OF THE POSSIBILITIES
}

\author{
Iva Vrkić \\ Središnja geofizička knjižnica \\ Prirodoslovno-matematički fakultet Sveučilišta u Zagrebu \\ ivavrkic@gfz.hr \\ Gordana Stubičan Ladešić \\ Središnja knjižnica za fiziku \\ Prirodoslovno-matematički fakultet Sveučilišta u Zagrebu \\ gordana@phy.hr
}

UDK / UDC 001.89:004.738.5:347.78

Izvorni znanstveni rad / Original scientific paper

Prihvaćeno / Accepted: 15.5.2017.

\section{Sažetak:}

Samoarhiviranjem znanstvenog rada na akademskim društvenim mrežama autor može povećati njegovu vidljivost, pretraživost, a time i korištenost u znanstvenoj zajednici. Politike samoarhiviranja pojedinog izdavača diktiraju mogućnost da autor koristi tu blagodat akademskih društvenih mreža. Kako bi se stekao uvid u trenutni stav izdavačke zajednice o tom pitanju i u to koliko je danas uopće otvorena mogućnost samoarhiviranja na akademskim društvenim mrežama, analizirane su politike i stavovi izdavača na uzorku od 59 izdavača u čijim je časopisima objavljivala znanstvena zajednica

Vjesnik bibliotekara Hrvatske 60, 2-3(2017), 137-151

ISSN 0507-1925

(C) VBH 2017. 
geofizičara s Geofizičkog odsjeka Prirodoslovno-matematičkog fakulteta u Zagrebu u razdoblju od 1980. do 2015. godine. Tako se dobila slika o stavovima izdavača koji su ključni za tu znanstvenu zajednicu.

Trenutni rezultati pokazuju nedefiniran ili nejasan stav velikog broja izdavača. Udio radova koje geofizičari ne smiju samoarhivirati na akademskim društvenim mrežama iznosi $61,2 \%$, ponajviše iz razloga nepostojanja jasne i istaknute politike izdavača. Oni radovi koji se smiju samoarhivirati na akademskim društvenim mrežama najčešće se mogu pohraniti u post-print inačici $(51,7$ \%), zatim pre-print inačici $(36,9 \%)$ i završnoj objavljenoj inačici $(11,4 \%)$.

Ključne riječi: akademske društvene mreže, politika samoarhiviranja izdavača, samoarhiviranje, autorska prava, post-print, pre-print

\section{Summary}

Self-archiving of scientific works on academic social networks can increase the author's visibility, searchability, usage, and citation of his papers in scientific community. Self-archiving policies of individual publishers dictate the possibilities of the author's use of this advantageous benefit of academic social networks. This survey provides an overview of the current attitudes of the publishing community and the possibility of self-archiving on academic social networks. The paper gives an insight into the attitudes of 59 publishers in whose journals the Croatian geophysicists (The Department of Geophysics, University of Zagreb) were publishing their papers in the period from 1980 to 2015. The analysis has resulted with an overview of the policies of the publishers crucial for this scientific community. The current results show that most publishers have a rather undefined or unclear attitude toward self-archiving. A large part, i.e. $61,2 \%$ of the scientific papers by geophysicists may not be self-archived on academic social networks, mostly due to unclear self-archiving policy of the publishers. The papers that may be self-archived on academic social networks may be posted in an accepted manuscript post-print version $(51,7 \%)$, a pre-print submitted version $(36,9 \%$ ), or in the final published version (version of record) $(11,4 \%)$.

Keywords: academic social networks, publisher self-archiving policies, self-archiving, copyright, post-print, pre-print 


\section{Uvod}

Jedan od načina da znanstvenik poveća vidljivost svog rada jest samoarhiviranje. Samoarhiviranje se može definirati kao postupak autorova pohranjivanja digitalne inačice znanstvene literature na mreži. Cilj samoarhiviranja jest znanstveni rad učiniti vidljivijim, pristupačnijim, pretraživijim i korištenijim. ${ }^{1}$

Znanstveni članci mogu biti samoarhivirani u repozitorij ili druge elektroničke arhive, na autorov osobni poslužitelj (npr. osobna mrežna stranica autora) ili na akademske društvene mreže.

Samoarhivirati se mogu različite inačice znanstvenih radova, ovisno o politici samoarhiviranja izdavača i njihovim pravilima. Sve inačice članaka koje se na taj način učine mrežno dostupnima nazivaju se jednim imenom - e-prints, a to može biti inačica rada prije recenzije (engl. pre-print), nakon recenzije (engl. post-print) ili završna objavljena inačica rada. ${ }^{2}$

Pitanje autorskih prava (engl. copyright issues) usko je povezano s procesom samoarhiviranja. Naime prilikom objavljivanja radova uobičajeno je da autor svoja autorska prava ugovorom ustupa izdavaču. Takvi se ugovori obično nazivaju Journal Publishing Agreement, Copyright transfer agreement, Exclusive Licence ili Non-exclusive Licence. ${ }^{3} \mathrm{Na}$ taj način autorska prava nad post-print inačicom i završnom objavljenom inačicom rada obično pripadaju izdavaču. Ukoliko politika samoarhiviranja nekog izdavača ne dopušta autoru da pohranjuje takve inačice radova, takav postupak može voditi u pravnu povredu. Iz tog je razloga prije samoarhiviranja post-print inačice ili završne inačice rada potrebno provjeriti dopušta li to politika izdavača časopisa u kojem je objavljen rad.

S druge strane, samoarhiviranje pre-print inačice rada ne može narušiti bilo kakve autorskopravne ugovore budući da je takva inačica rada stvorena prije slanja članka izdavaču. Zbog toga samoarhiviranje pre-print inačice rada ne može biti pravna stvar niti može izazvati pravnu povredu. ${ }^{4}$

Svaki ozbiljniji znanstveni izdavač ima objavljenu politiku samoarhiviranja te autor prije pohranjivanja svog rada treba provjeriti koju inačicu punog teksta svog članka smije samoarhivirati i pod kojim uvjetima.

\footnotetext{
1 Cerejo, Clarinda. How to make your paper more accessible through self-archiving. // Editage Insights. 2013. [citirano: 2016-09-01]. Dostupno na http:/www.editage.com/insights/ how-to-make-your-paper-more-accessible-through-self-archiving.

2 Isto.

3 Laakso, Mikael. Green open access policies of scholarly journal publishers: a study of what, when, and where self-archiving is allowed. // Scientometrics 99, 2(2014), 475-494. DOI: 10.1007/s11192-013-1205-3.

4 Cerejo, Clarinda. Nav. dj.
} 
U tu svrhu može se koristiti baza podataka SHERPA/RoMEO ${ }^{5}$, koja na jednom mjestu okuplja pravila izdavača o samoarhiviranju. Navedena baza omogućuje uvid u detaljne informacije o samoarhiviranju časopisa: inačicu članka koja se smije pohraniti (pre-print, post-print, završna objavljena inačica rada), uvjete i način samoarhiviranja, kao i poveznice na izdavača i izdavačevu politiku.

SHERPA/RoMEO uvodi i jednostavan način klasificiranja izdavačevih pravila samoarhiviranja po bojama, pa se tako razlikuju četiri kategorije: zelena - izdavač dopušta samoarhiviranje pre-printa i post-printa, plava - izdavač dopušta samoarhiviranje post-printa, žuta - dopušteno je samoarhiviranje pre-printa i bijela - izdavač ne dopušta samoarhiviranje. Takav način označavanja pravila samoarhiviranja po bojama, zbog njegove jednostavnosti i prepoznatljivosti, usvojili su i neki izdavači.

\subsection{Koji su pozitivni učinci i prednosti samoarhiviranja?}

Autorovo pohranjivanje javno dostupne digitalne inačice vlastitog rada na mreži povećava vidljivost znanstvenih istraživanja, to je besplatan način za povećanje broja pogleda, preuzimanja (engl. download) i citiranja znanstvenog rada $^{6}$; povećava istraživačevu prepoznatljivost u nekom znanstvenom području - što može povećati njegove izglede za stjecanje raznih potpora u budućnosti ${ }^{7}$; omogućava autoru da prezentira svoje istraživanje prije nego što je objavljeno u časopisu (samoarhiviranje pre-print inačice rada) - što je posebno korisno za visokoutjecajne pronalaske koji se moraju diseminirati u što kraćem vremenskom razdoblju ${ }^{8}$; pomaže istraživačima da na jednom mjestu spreme svoj cjelokupni znanstveni opus (popis radova s bibliografskim podacima i cjelovitim tekstovima) kojem će imati jednostavan pristup ; omogućava pohranjivanje cjelokupne produkcije neke institucije na jedno mjesto - što može privući vanjska financiranja, pažnju fakulteta i studenata. ${ }^{10}$

\footnotetext{
5 Sherpa/Romeo : publisher copyright policies \& self-archiving [citirano: 2017-05-15]. Dostupno na http://www.sherpa.ac.uk/romeo/index.php.

6 Lawrence, Steve. Free online availability substantially increases a paper's impact. // Nature 411(2001), str. 521.

7 Cerejo, Clarinda. Nav. dj.

8 Isto.

9 SPARC Institutional Repository Checklist \& Resource Guide [citirano: 2016-08-20]. Dostupno na https://sparcopen.org/wp-content/uploads/2016/01/IR_Guide_Checklist_v1_0.pdf.

10 Isto.
} 


\subsection{Ako je toliko pozitivnih učinaka samoarhiviranja, zašto ono nije više uvriježeno u znanstvenoj zajednici?}

Alma Swan i Sheridan Brown u svojoj studiji iz 2005. godine navode nekoliko razloga za to: nedostatak svijesti o prednostima samoarhiviranja, briga zbog kvalitete samoarhiviranih članaka, strah od kršenja politike časopisa o autorskim pravima i kršenja dozvola samoarhiviranja, percepcija da je samoarhiviranje teško i uzima puno vremena i strah od narušavanja postojećeg modela znanstvenog izdavaštva. ${ }^{11}$

Do sličnih je rezultata došao Jihyun Kim 2010. godine, kada je istražio čimbenike koji utječu na motivaciju profesora sa 17 američkih sveučilišta da samoarhiviraju svoje radove na javnim web-stranicama i raznim open acces arhivima. Pomoću dva teorijska modela (STIN-model i teorija društvenih razmjena) otkrio je da na motivaciju znanstvenika da samoarhiviraju svoje radove negativno utječu njihova dob, briga o autorskim pravima, potrebne tehničke vještine i trud koji moraju uložiti u proces samoarhiviranja. ${ }^{12}$

Istraživanja koja dokazuju veći citatni utjecaj vidljivijih i otvoreno dostupnih članaka dovoljan su motiv da znanstvenici ulože vrijeme u samoarhiviranje svojih radova u javno dostupnim repozitorijima. ${ }^{13}$

Većina izdavača dopušta pohranjivanje pre-printa i post-printa u institucijske repozitorije, pa čak i na autorove osobne web-stranice. Radovi se mogu pohraniti odmah ili nakon isteka razdoblja embarga (engl. embargo period). U akademskom izdavaštvu pojam razdoblja embarga odnosi se na razdoblje nakon službenog objavljivanja nekog članka tijekom kojega nije dopušten pristup korisnicima koji nemaju plaćen pristup ili nije dopuštena mogućnost samoarhiviranja na javno dostupna mrežna mjesta. Razdoblje embarga određuju izdavači, a u svrhu osiguravanja vlastitih prihoda.

U zadnje vrijeme uvode se i obveze pohranjivanja istraživačkih podataka u digitalne repozitorije u otvorenom pristupu kako bi rezultati istraživanja bili dostupni cjelokupnoj znanstvenoj zajednici. Time se sve više potiče razvoj institucijskih repozitorija koji preuzimaju ulogu malih riznica znanstvene produkcije institucije. Jedan od bitnih izdavačevih uvjeta za pohranjivanje radova odnosi se na obavezno pohranjivanje u neprofitne baze podataka. Zbog navedenog uvjeta

\footnotetext{
11 Swan, Alma; Sheridan Brown. Open access self-archiving : an author study. Key Perspectives. 2005. [citirano: 2016-09-17]. Dostupno na http://cogprints.org/4385/1/jisc2.pdf.

12 Kim, Jihyun. Faculty self-archiving : motivations and barriers. // Journal of the American Society for Information Science and Technology 61(2010), 1909-1922.

13 Hebrang Grgić, Ivana. Citatna prednost znanstvenih radova objavljenih u otvorenom pristupu. Nerecenzirana inačica rada (preprint) iz ožujka 2013. [citirano: 2016-09-05]. Dostupno na http://darhiv.ffzg.unizg.hr/4140/1/citatnaprednost_preprint_IHG.pdf.
} 
isti radovi ne smiju se pohraniti na akademskim društvenim mrežama jer su profitne (i time su u nepovoljnijem položaju s obzirom na institucijske repozitorije).

Danas znanstvenici koriste web ne samo da bi komunicirali jedni s drugima već i da bi objavili i prikupili znanstvene radove.

Zato se znanstvene publikacije pojavljuju na različitim mrežnim kanalima, kao što su osobne mrežne stranice, web-stranice istraživačkih grupa, institucijski repozitoriji, istraživački blogovi, predmetni repozitoriji (npr. ArXiv, RePEc) ili društvene mreže fokusirane na znanstvenike (npr. Mendeley, Academia.edu, ResearchGate). ${ }^{14}$ One se još nazivaju akademskim društvenim mrežama (engl. Academic Social Network) ili znanstvenim mrežama za suradnju (engl. Scholarly Collaboration Network, SCN).

U ovom radu usmjerit ćemo se na mogućnosti samoarhiviranja znanstvenih radova na akademskim društvenim mrežama koje dopuštaju samoarhiviranje, kao što su Mendeley, Academia.edu, ResearchGate itd.

\subsection{Zašto bi uopće znanstvenik samoarhivirao dopuštenu inačicu cjelovitog teksta svog znanstvenog rada na neku akademsku društvenu mrežu, kao što je npr. ResearchGate, Mendeley ili Academia.edu?}

Alberto Martin-Matin i suradnici 2016. godine identificirali su najcitiranije dokumente u Google Scholaru i definirali njihove osnovne karakteristike te su unutar svog istraživanja propitali koliko je najcitiranijih dokumenata javno dostupno i koje su glavne organizacije koje omogućavaju servis za pristupanje (engl. provider) tim cjelovitim tekstovima (engl. full text) dokumenata.

Udio dokumenata kojima se može pronaći cjelovit tekst iznosi 40 \% od sveukupnog skupa najcitiranijih dokumenata na Google Scholaru. Zamijećen je i pozitivan trend kroz analizirano razdoblje - od 1950. do 1959. samo $25.93 \%$ dokumenata ima poveznicu na slobodno dostupan cjeloviti tekst, a u razdoblju od 2010. do 2013 čak $66.84 \%$.

Isporučitelj (provider) koji osigurava najveći udio cjelovitih tekstova jest National Institutes of Health (zahvaljujući centralnom repozitoriju Pubmed), a odmah iza njega slijedi akademska društvena mreža ResearchGate. ${ }^{15}$

\footnotetext{
14 Mas-Bleda, Amalia. Do highly cited researchers successfully use the social web? // Scientometrics 101, 1(2014), 337-356. DOI: 10.1007/s11192-014-1345-0.

15 Martin-Martin, Alberto; Enrique Orduna-Malea; Juan M. Ayllon; Emilio Delgado Lopez-Cozar. A two-sided academic landscape: portrait of highly-cited documents in Google Scholar (19502013). // ArXiv.org. 2016. [citirano: 2016-10-20]. Dostupno na https://arxiv.org/abs/1607.02861.
} 
Tako visoko mjesto na rang-listi isporučitelja koji osiguravaju cjelovite tekstove visoko citiranih radova pokazuje važno mjesto ResearchGatea u smislu točke oko koje se okupljaju visoko citirani radovi i mjesta gdje se pronalaze i pretražuju inačice cjelovitih tekstova radova.

Iz navedenoga se može zaključiti da ta akademska mreža već sada ima ugled i kapacitet da postane jedan od prvih izbora nekom znanstveniku kao mjesto gdje će samoarhivirati dopuštenu inačicu svog znanstvenog rada ne bi li mu povećao vidljivost.

ResearchGate je akademska društvena mreža s 11 milijuna korisnika. Osnovali su je 2008. godine virolozi dr. Ijad Madisch i Sören Hofmayer te IT-stručnjak Horst Fickenscher, s ciljem da povežu znanstvenike diljem svijeta te učine istraživanja otvorenima za sve.

Središnja točka te mreže jest profil korisnika/znanstvenika, a jezgra profila jesu njegovi doprinosi/radovi (engl. contributions).

Osim profila, postoji još nekoliko funkcija koje osigurava ta mreža, a jedna je od njih i samoarhiviranje radova. Tako ResearchGate zapravo dobiva i funkcionalnost repozitorija. ${ }^{16}$

Academia.edu definira se kao platforma za akademske korisnike za dijeljenje znanstvenih radova. Kompanija kao svoju misiju ističe ubrzavanje istraživanja u svijetu, a namijenila je svoju mrežu znanstvenicima za dijeljenje njihovih istraživanja, praćenje utjecaja njihovih istraživanja i praćenje istraživanja njihovih kolega. Mreža ima 51 milijun članova, no nisu svi aktivni članovi. Važniji je podatak da je unutar nje već podijeljeno 18 milijuna radova. ${ }^{17}$

Mendeley je besplatan servis za organizaciju referenci (engl. reference manager), a ujedno i akademska društvena mreža. ${ }^{18}$

\section{Istraživanje}

\subsection{Svrha istraživanja}

Ovim radom želi se dobiti uvid u mogućnost samoarhiviranja znanstvenog članka na akademskim društvenim mrežama, a na primjeru znanstvenika s Geofizičkog odsjeka u Zagrebu. Želi se istražiti u kojoj mjeri izdavači (na uzorku izdavača kod kojih objavljuju znanstvenici s Geofizičkog odsjeka) imaju jasnu politiku o samoarhiviranju na akademske društvene mreže i kako je ta politika definirana.

16 ResearchGate : about us [citirano: 2017-05-15]. Dostupno na https://www.researchgate.net/ about.

17 Academia.edu [citirano: 2017-05-15]. Dostupno na https://www.academia.edu/.

18 Mendeley [citirano: 2017-05-15]. Dostupno na https://www.mendeley.com/. 
Potrebno je vidjeti na kakav način izdavači diktiraju smije li autor postaviti neku inačicu članka na akademske društvene mreže jer je to temelj i preduvjet otvaranja mogućnosti znanstvenicima da svoje radove učine vidljivijima akademskoj zajednici i tako iskoriste blagodati akademskih društvenih mreža.

\subsection{Metodologija}

Kao temelj analize izdavača u čijim časopisima objavljuju znanstvenici s Geofizičkog odsjeka korištena je platforma Hrvatske znanstvene bibliografije (CROSBI), i to zbog njezine sveobuhvatnosti i cjelovitosti. Iz nje će se vidjeti u kojim časopisima naši geofizičari objavljuju, a kako bi se doznalo koje je politike izdavača potrebno analizirati.

Skup autora čije radove u CROSBI-ju analiziramo činit će mala znanstvena zajednica, tj. svi aktivni istraživači (21 istraživač) s Geofizičkog odsjeka Prirodoslovno-matematičkog fakulteta u Zagrebu.

Budući da se kroz članke u časopisima odvija glavnina legitimnog komuniciranja u znanosti ${ }^{19}$, ispitat će se upisani bibliografski podaci za kategorije koje se odnose na radove u časopisu.

Istraživači s Geofizičkog odsjeka upisali su u CROSBI u razdoblju od 1980. do 2015. godine 384 znanstvena rada u navedenim kategorijama.

Za cjelokupan skup radova istražit će se u kojim su časopisima (kojih izdavača) geofizičari objavljivali u posljednjih 35 godina te kakva su pravila i politike samoarhiviranja članaka na akademskim društvenim mrežama tih izdavača.

\subsection{Rezultati}

U ovoj analizi korišten je skup od 384 članka znanstvenika s Geofizičkog odsjeka Prirodoslovno-matematičkog fakulteta u Zagrebu.

Iz tog skupa dobio se uvid u časopise u kojima su znanstvenici s Geofizičkog odsjeka objavljivali.

Svi znanstveni članci znanstvenika s Geofizičkog odsjeka upisani u CROSBI objavljeni su u 117 časopisa koje objavljuje 59 izdavača.

Za 7 časopisa nije pronađen izdavač, pa tako politika samoarhiviranja nije mogla biti analizirana.

Uvid u politike samoarhiviranja dobiven je pregledavanjem mrežnih stranica izdavača. Neke mrežne stranice ne donose cjelovite informacije, pa je bilo potreb-

19 Šercar, Tvrtko. Časopis kao sredstvo institucionalizacije znanosti. // Acta Stomatologica Croatica 21, 4(1987), 319-323. 
no izravno kontaktirati izdavača e-poštom. Na taj način dobivene su informacije o dopuštenju samoarhiviranja radova na akademske društvene mreže kod izdavača Wiley $^{20}$, Springer ${ }^{21}$, Elsevier ${ }^{22}$, European Geosciences Union/Copernicus Publications $^{23}$, Schweizerbart Science Publishers ${ }^{24}$, De Gruyter Open ${ }^{25}$, Nature Publishing Group ${ }^{26}$ i Oxford University Press. ${ }^{27}$

Ukupno 11 izdavača (koji su objavili 105 članaka iz našeg skupa) izdaje OA-časopise i nema određeni istaknuti stav na mrežnim stranicama o samoarhiviranju na akademske društvene mreže.

Za ukupno 32 izdavača i 40 radova nema nikakvih podataka o dijeljenju radova na akademskim društvenim mrežama i općenito o politici samoarhiviranja.

Nakon analize politike samoarhiviranja svih izdavača, vidljivi su stavovi izdavača prema politici samoarhiviranja na akademskim mrežama.

Za potrebe ove analize proučene su politike i stavovi 59 izdavača u čijim su časopisima objavljivali geofizičari. Čak 43 izdavača ne donose nikakav stav o samoarhiviranju i društvenim akademskim mrežama (a njih 11 su open-access izdavači bez određene istaknute politike). Od 16 velikih izdavača u čijim je časopisima objavljena glavnina radova geofizičara (Wiley, Springer, Elsevier, AMS, European Geosciences Union/Copernicus Publications, Schweizerbart Science Publishers, Seismological Society of America, EDP Sciences, Inderscience, De Gruyter Open, Nature Publishing Group, Oxford University Press, Taylor \& Francis, Royal Society of Chemistry, Optical Society of America, Quintessence Publishing), a koji imaju iskazanu politiku samoarhiviranja na svojim mrežnim stranicama ili su ju jasno iskazali u odgovoru e-poštom, čak 7 njih ne dopušta nikakvu objavu nijedne inačice rada na akademskim društvenim mrežama. Podjednak broj izdavača dopušta samoarhiviranje pre-print inačice (3 izdavača), post-print inačice s određenim embargom ( 3 izdavača) ili završne inačice rada $\mathrm{s}$ određenim embargom (3 izdavača) (slika 1).

\footnotetext{
20 Fajardo, Erica. Self-archiving policy question - Wiley. Privatna poruka. (1.7.2016.)

21 Tanriverdi, Feyme. Self-archiving policy question - Springer. Privatna poruka. (19.7.2016.)

22 Stingelin, Laura. Self-archiving policy question - Elsevier. Privatna poruka. (12.7.2016.)

23 Edig, Xenia van. Self-archiving policy question - Copernicus publications. Privatna poruka. (6.7.2016.)

24 Nägele, Andreas. Self-archiving policy question - Schweizerbart. Privatna poruka. (7.7.2016.)

25 Linhardt, Tanja. Self-archiving policy question - De Gruyter. Privatna poruka. (20.7.2016.)

26 Monaghan, Jess. Self-archiving policy question - Nature publishing group. Privatna poruka. (14.7.2016.)

27 Eyre, Louise. Self-archiving policy question - OUP. Privatna poruka. (26.7.2016.)
} 


\section{Prikaz izdavačkih politika samoarhiviranja na akademskim društvenim mrežama}

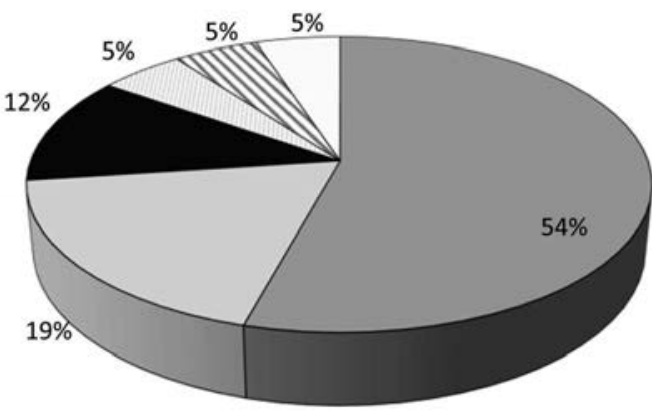

口Izdavači bez stava o samoarhiviranju radova

口Open-access izdavači bez naglašene politike samoarhiviranja

- Izdavači zabranjuju samoarhiviranje bilo kakve inačice članka

口Izdavači dopuštaju samoarhiviranje pre-print inačice rada

Izdavači dopuštaju samoarhiviranje post-print inačice rada

口lzdavači dopuštaju samoarhiviranje završne objavljene inačice rada

Slika 1. Stavovi izdavača (u čijim časopisima geofizičari objavlju) o autorovu pravu na samoarhiviranje inačice njegova rada na akademskim društvenim mrežama

Moguće je uočiti koliko radova i u kojoj inačici skupina geofizičara s PMF-a smije samoarhivirati na akademskim mrežama.

U posljednjih 35 godina ta je skupina objavila 384 rada (upisanih u CROSBI).

Ako se želi detaljnije analizirati te udjele, može se uvidjeti da je udio radova koji se ne smiju samoarhivirati (235 radova) zapravo zbroj radova u časopisima bez dostupne politike samoarhiviranja na akademskim mrežama (145 radova), radova u časopisima za koje ne možemo ni pronaći mrežno mjesto ili kontakt izdavača (24 rada) te radova za koje vrijedi pravilo izdavača da se ne smije samoarhivirati nijedna inačica (66 radova).

Udio radova koji se smiju samoarhivirati u nekoj inačici (149 radova) zapravo je zbroj članaka za koje vrijedi pravilo izdavača da se smije samoarhivirati preprint inačica na društvenim mrežama (55 radova), članaka za koje vrijedi pravilo da je dopušteno postaviti post-print inačicu rada (77 radova), ali s embargom od 6 ili 12 mjeseci ili obvezom uklanjanja pdf-a post-printa u trenutku službene objave (izdavač AMS) i članaka za koje vrijedi pravilo da je dopušteno samoarhivirati završnu objavljenu inačicu rada (17 radova) - uz pravilo embarga od 12 mjeseci za 4 rada (slika 2). 


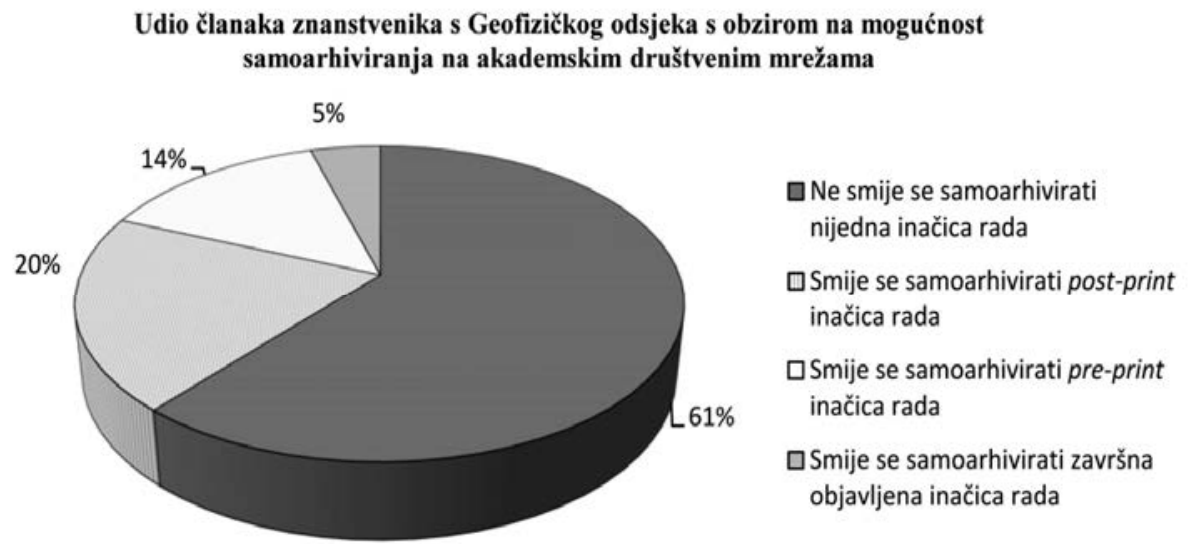

Slika 2. Udio članaka znanstvenika s Geofizičkog odsjeka objavljenih 1980.2015. s obzirom na mogućnost samoarhiviranja na akademskim društvenim mrežama

\subsection{Rasprava}

Prema rezultatima ove analize vidljivo je da čak 72,9 \% izdavača u kojima geofizičari s PMF-a objavljuju uopće nema stav ni istaknutu politiku prema samoarhiviranju na akademskim društvenim mrežama. Takvo nepostojanje jasnog i istaknutog stava izdavača zapravo onemogućava znanstvenike da samoarhiviraju svoje radove.

Ostatak od 27,1 \% izdavača (16 izdavača) čine veliki izdavači koji imaju iskazane politike samoarhiviranja na svojim mrežnim stranicama. No čak polovica navedenih izdavača ima nejasne odrednice na svojim mrežnim stranicama vezane uz mogućnost samoarhiviranja na akademskim društvenim mrežama i potrebno im je uputiti elektroničkom poštom poseban upit o mogućnosti takva samoarhiviranja. Iz toga proizlazi da tek 8 izdavača ima jasnu i istaknutu politiku samoarhiviranja na akademskim mrežama.

Nakon prikupljanja podataka s mrežnih stranica i odgovora dobivenih elektroničkom poštom moguće je promotriti kako se tih 16 velikih izdavača odnosi prema mogućnosti samoarhiviranja na akademskim društvenim mrežama (tablica 1). Vidljivo je da gotovo polovica njih (7 izdavača) ne dopušta nikakvo samoarhiviranje, a ostali u istom omjeru dopuštaju pre-print inačicu, post-print inačicu s embargom i završnu objavljenu inačicu s embargom. 
Tablica 1. Stavovi izdavača prema samoarhiviranju na akademskim društvenim mrežama

\begin{tabular}{|c|c|c|}
\hline Izdavač & $\begin{array}{l}\text { Broj radova } \\
\text { geofizičara s } \\
\text { PMF-a koji su ob- } \\
\text { javljeni u časopisi- } \\
\text { ma tog izdavača }\end{array}$ & $\begin{array}{l}\text { Stav izdavača prema samoarhiviranju na } \\
\text { akademskim društvenim mrežama }\end{array}$ \\
\hline Wiley & 55 & $\begin{array}{l}\text { Nije dopušteno samoarhiviranje na } \\
\text { akademskim društvenim mrežama. }\end{array}$ \\
\hline Springer & 54 & $\begin{array}{l}\text { Dopušteno je samoarhivirati post-print } \\
\text { inačicu rada uz } 12 \text { mjeseci embarga nakon } \\
\text { objavljivanja, uz podatke o službenoj inačici } \\
\text { i uz poveznicu na nju. }\end{array}$ \\
\hline Elsevier & 45 & $\begin{array}{l}\text { Dopušteno je samoarhivirati samo pre-print } \\
\text { inačicu rada. }\end{array}$ \\
\hline AMS & 20 & $\begin{array}{l}\text { Dopušteno je samoarhivirati privremeni } \\
\text { pre-print ili post-print do trenutka službene } \\
\text { objave rada, a nakon toga je potrebno do } \\
\text { prvog dana u idućem mjesecu ukloniti tu } \\
\text { inačicu rada. }\end{array}$ \\
\hline $\begin{array}{l}\text { European Geoscienc- } \\
\text { es Union / Copernicus } \\
\text { Publications }\end{array}$ & 12 & $\begin{array}{l}\text { Dopušteno je samoarhivirati sve inačice } \\
\text { rada, no savjetuje se dijeliti završnu objavl- } \\
\text { jenu inačicu rada. }\end{array}$ \\
\hline $\begin{array}{l}\text { Schweizerbart Sci- } \\
\text { ence Publishers }\end{array}$ & 9 & $\begin{array}{l}\text { Dopušteno je samoarhivirati samo pre-print } \\
\text { inačicu rada. }\end{array}$ \\
\hline $\begin{array}{l}\text { Seismological Society } \\
\text { of America }\end{array}$ & 5 & $\begin{array}{l}\text { Nije dopušteno samoarhiviranje na } \\
\text { akademskim društvenim mrežama. }\end{array}$ \\
\hline EDP Sciences & 4 & $\begin{array}{l}\text { Dopušteno je samoarhivirati završnu obja- } \\
\text { vljenu inačicu rada uz } 12 \text { mjeseci embarga } \\
\text { nakon objavljivanja. }\end{array}$ \\
\hline Inderscience & 3 & $\begin{array}{l}\text { Dopušteno je samoarhivirati post-print } \\
\text { inačicu rada uz } 6 \text { mjeseci embarga nakon } \\
\text { objavljivanja. }\end{array}$ \\
\hline De Gruyter Open & 2 & $\begin{array}{l}\text { Nije dopušteno samoarhiviranje na } \\
\text { akademskim društvenim mrežama. }\end{array}$ \\
\hline $\begin{array}{l}\text { Nature Publishing } \\
\text { Group }\end{array}$ & 1 & $\begin{array}{l}\text { Nije dopušteno samoarhiviranje na } \\
\text { akademskim društvenim mrežama. }\end{array}$ \\
\hline $\begin{array}{l}\text { Oxford University } \\
\text { Press }\end{array}$ & 1 & $\begin{array}{l}\text { Dupušteno je samoarhivirati post-print } \\
\text { inačicu rada ili završnu objavljenu inačicu. }\end{array}$ \\
\hline
\end{tabular}




\begin{tabular}{|l|c|l|}
\hline Izdavač & $\begin{array}{l}\text { Broj radova } \\
\text { geofizičara s } \\
\text { PMF-a koji su ob- } \\
\text { javljeni u časopisi- } \\
\text { ma tog izdavača }\end{array}$ & $\begin{array}{l}\text { Stav izdavača prema samoarhiviranju na } \\
\text { akademskim društvenim mrežama }\end{array}$ \\
\hline Taylor \& Francis & 1 & $\begin{array}{l}\text { Dopušteno je samoarhivirati pre-print inači- } \\
\text { cu rada odmah, a post-print inačicu uz 12 } \\
\text { mjeseci embarga nakon objavljivanja. }\end{array}$ \\
\hline $\begin{array}{l}\text { Royal Society of } \\
\text { Chemistry }\end{array}$ & 1 & $\begin{array}{l}\text { Nije dopušteno samoarhiviranje na } \\
\text { akademskim društvenim mrežama. }\end{array}$ \\
\hline $\begin{array}{l}\text { Optical Society of } \\
\text { America }\end{array}$ & 1 & $\begin{array}{l}\text { Nije dopušteno samoarhiviranje na } \\
\text { akademskim društvenim mrežama. }\end{array}$ \\
\hline $\begin{array}{l}\text { Quintessence Pub- } \\
\text { lishing }\end{array}$ & 1 & $\begin{array}{l}\text { Nije dopušteno samoarhiviranje na } \\
\text { akademskim društvenim mrežama. }\end{array}$ \\
\hline $\begin{array}{l}\text { Izdavači bez stava } \\
\text { prema samoarhivi- } \\
\text { ranju radova }\end{array}$ & 145 & $/$ \\
\hline $\begin{array}{l}\text { Članci za koje se ne } \\
\text { može pronaći izvor } \\
\text { izdavača }\end{array}$ & 24 & $/$ \\
\hline
\end{tabular}

Znanstvenici s Geofizičkog odsjeka ne objavljuju u svim časopisima izdavača $\mathrm{u}$ jednakim omjerima, te je zbog toga utjecaj ograničenja i zabrane samoarhiviranja nekih izdavača na njih veći ili manji. Ukoliko se promotri koliki je udio članaka objavljenih u razdoblju od 1980. do 2015., svakako je više radova koji se ne smiju samoarhivirati $(61,2 \%)$, i to najviše baš iz razloga nepostojanja jasne i istaknute politike izdavača. Oni radovi koji se smiju samoarhivirati na akademske društvene mreže najčešće se mogu postavljati u post-print inačici $(51,7 \%)$, zatim pre-print inačici (36,9 \%), a najmanje u završnoj objavljenoj inačici (11,4 \%).

\section{Zaključak}

Samoarhiviranjem dopuštene inačice znanstvenog rada na akademske društvene mreže autor promovira svoj rad, čini ga vidljivijim i pristupačnijim. Postoje dvije međusobno povezane prepreke koje onemogućavaju potencijal i korisnost takvih rastućih mreža.

Prva je prepreka nepostojanje politike samoarhiviranja na akademskim mrežama nekih izdavača, nejasna i neistaknuta izdavačeva pravila ili zabrana izdavača da se rad pohrani, bude javno dostupan i da se podijeli s drugim znanstvenicima. Dopuštanje postavljanja raznih inačica radova s određenim razdobljem embarga također je jedno od rješenja koja izdavači dopuštaju. 
Druga je prepreka izravno povezana s prvom i odnosi se na angažman koji autor mora uložiti da bi proniknuo u autorskopravna pitanja vezana uz samoarhiviranje nekog članka. Znanstvenici često nemaju vremena ni motivacije tražiti i proučavati raznovrsne ili nejasne politike izdavača u čijem su časopisu objavili rad.

Politike izdavača i fukcionalnosti društvenih akademskih mreža često se mijenjaju i potrebno je pratiti taj turbulentan i nimalo jednostavan sustav. Pomaganje i usmjeravanje znanstvenika u tom području otvaraju visokoškolskim knjižničarima mogućnost stvaranja još jedne vrijedne i korisne knjižnične usluge.

\section{LITERATURA}

Cerejo, Clarinda. How to make your paper more accessible through self-archiving. // Editage Insights. 2013 [citirano: 2016-09-01]. Dostupno na http://www.editage. com/insights/how-to-make-your-paper-more-accessible-through-self-archiving

Edig, Xenia van. Self-archiving policy question - Copernicus publications. Privatna poruka. (6.7.2016.)

Eyre, Louise. Self-archiving policy question - OUP. Privatna poruka. (26.7.2016.)

Fajardo, Erica. Self-archiving policy question - Wiley. Privatna poruka. (1.7.2016.)

Hebrang Grgić, Ivana. Citatna prednost znanstvenih radova objavljenih u otvorenom pristupu. Nerecenzirana inačica rada (preprint) iz ožujka 2013. [citirano: 2016-09-05]. Dostupno na http://darhiv.ffzg.unizg.hr/4140/1/citatnaprednost_preprint_IHG.pdf

Kim, Jihyun. Faculty self-archiving: motivations and barriers // Journal of the American Society for Information Science and Technology 61(2010), 1909-1922.

Laakso, Mikael. Green open access policies of scholarly journal publishers: a study of what, when, and where self-archiving is allowed. // Scientometrics 99, 2(2014), 475494. DOI: $10.1007 / \mathrm{s} 11192-013-1205-3$

Lawrence, Steve. Free online availability substantially increases a paper's impact. // Nature 411(2001), 521.

Linhardt, Tanja. Self-archiving policy question - De Gruyter. Privatna poruka. (20.7.2016.)

Martin-Martin, Alberto; Enrique Orduna-Malea; Juan M. Ayllon; Emilio Delgado Lopez-Cozar. A two-sided academic landscape: portrait of highly-cited documents in Google Scholar (1950-2013). // ArXiv.org. 2016. [citirano: 2016-10-20]. Dostupno na https://arxiv.org/abs/1607.02861

Mas-Bleda, Amalia. Do highly cited researchers successfully use the social web? // Scientometrics 101, 1(2014), 337-356. DOI: 10.1007/s11192-014-1345-0 
Monaghan, Jess. Self-archiving policy question - Nature publishing group. Privatna poruka. (14.7.2016.)

Nägele, Andreas. Self-archiving policy question - Schweizerbart. Privatna poruka. (7.7.2016.)

SPARC Institutional Repository Checklist \& Resource Guide [citirano: 2016-08-20]. Dostupno na https://sparcopen.org/wp-content/uploads/2016/01/IR_Guide_Checklist_v1_0.pdf

Stingelin, Laura. Self-archiving policy question - Elsevier. Privatna poruka. (12.7.2016.)

Swan, Alma; Sheridan Brown. Open access self-archiving : an author study. Key Perspectives. 2005. [citirano: 2016-09-17]. Dostupno na http://cogprints.org/4385/1/ jisc2.pdf

Šercar, Tvrtko. Časopis kao sredstvo institucionalizacije znanosti. // Acta Stomatologica Croatica 21, 4(1987), 319-323.

Tanriverdi, Feyme. Self-archiving policy question - Springer. Privatna poruka. (19.7.2016.) 